\title{
Menakar Struktur Kepemilikan Saham dan Kinerja Perusahaan
}

\author{
Mayroza Wiska \\ Universitas Dharmas Indonesia (UNDHARI), Dharmasraya, Indonesia \\ mayrozawiska@gmail.com
}

\begin{abstract}
Analysis of Performance Shareholding Structure of the Company (a mining company listed on the Indonesia Stock Exchange. In preparation of this paper, the authors have conducted research on the Indonesia Stock Exchange (Capital Market Information Center-Padang) Jl.Pondok 90 Padang. The purpose of this study was to determine the effect of ownership structure on corporate performance in the mining company listed on the Indonesia Stock Exchange (BEI. The analysis in this research using descriptive statistics, classic assumption test (test mulitikolonieritas, autokolerasi test, normality test), analysis of regression coefficient test, partial regression coefficients ( $t$ test), testing regression coefficients together (test $f$ ). As for the overall analysis of this data with the help of a software program SPSS version 21.0 for Windows. Results of this study concluded that: (1) public ownership structure positively affects the performance of companies in the mining company listed on the Indonesia Stock Exchange (BEI). (2) The structure of stock ownership is not a positive influence on the company's performance in the mining company listed on the Indonesia Stock Exchange (BEI). (3) The structure of public ownership and foreign ownership together affect the company's performance in the mining company listed on the Indonesia Stock Exchange (BEI).
\end{abstract}

\section{Keywords : Public Ownership; Foreign Ownership; Company performance}

\begin{abstract}
ABSTRAK
Penulis telah mengadakan penelitian pada PT Bursa Efek Indonesia (Pusat Informasi Pasar Modal-Padang) JL.Pondok No.90 Padang. Penelitian ini bertujuan untuk mengetahui pengaruh struktur kepemilikan saham terhadap kinerja perusahaan pada perusahaan pertambangan yang terdaftar di Bursa Efek Indonesia (BEI). Analisis dalam penelitian ini menggunakan statistik deskriptif, uji asumsi klasik (uji mulitikolonieritas, uji autokolerasi, uji normalitas), analisi uji koefisien regresi, koefisien regresi secara parsial (uji t), uji koefisien regresi secara bersamasama (uji f). Adapun keseluruhan analisis data ini dengan menggunakan software program SPSS version 21.0 for windows. Hasil penelitian ini menyimpulkan bahwa: (1) Struktur kepemilikan publik berpengaruh positif terhadap kinerja perusahaan pada perusahaan pertambangan yang terdaftar di Bursa Efek Indonesia (BEI). (2) Struktur kepemilikan saham tidak berpengaruh positif terhadap kinerja perusahaan pada perusahaan pertambangan yang terdaftar di Bursa Efek Indonesia (BEI). (3) Struktur kepemilikan Publik dan kepemilikan Asing secara bersama-sama berpengaruh terhadap kinerja perusahaan pada perusahaan pertambangan yang terdaftar di Bursa Efek Indonesia (BEI) tahun 2010-2014.
\end{abstract}

Kata kunci : Kepemilikan Publik; Kepemilikan Asing; Kinerja Perusahaan (ROA) 


\section{PENDAHULUAN}

Dalam dunia usaha, Persaingan yang begitu ketat dan kuat membuat perusahaan memikirkan cara bertahan agar mampu bersaing dengan usaha dan bisnis lainnya. Hal ini juga terlihat dengan cara perusahaan memaksimalkan keuntungan yang diperoleh oleh perusahaan. Salah satu nya jika perusahaan tersebut sudah terdaftar di bursa saham, maka publik bisa membeli saham perusahaan dengan bebas. Sehingga perusahaan bisa menghimpun dana secara luas dari masyarakat.

Struktur kepemilikan saham mampu memengaruhi jalannya perusahaan yang pada akhirnya berpengaruh pada kinerja perusahaan dalam mencapai tujuan perusahaan yaitu maksimalisasi nilai perusahaan. Hal ini disebabkan oleh adanya kontrol dari para pemegang saham. Struktur kepemilikan saham dalam perusahaan pada umumnya antara lain meliputi kepemilikan institusional, dan kepemilikan manajerial, serta kepemilikan saham oleh individual atau publik.

Nilai perusahaan merupakan persepsi investor terhadap suatu perusahaan, perusahaan yang memiliki nilai tinggi akan menjadi keinginan para pemilik perusahaan. Nilai yang tinggi akan menunjukkan bahwa kemakmuran para pemegang saham juga tinggi. Kekayaan pemegang saham dan perusahaan direpresentasikan oleh harga pasar dari saham yang merupakan cerminan dari keputusan investasi, untuk itu para manajer berupaya untuk menggunankan laporan keuangan yang merupakan cerminan keadaan perusahaan, dan juga sebagai alat komunikasi antara pemilik dengan pengelola perusahaan sebagai media untuk mengkomunikasikan kepada pihak internal perusahaan dan pihak eksternal.

Kinerja keuangan adalah salah satu tolak ukur dalam menilai perusahaan, kondisi keuangan yang bagus cenderung menarik perhatian investor, untuk itu manajemen berusaha untuk memenuhi harapan dari analisis keuangan atau manajemen (yang diwakili oleh peramalan laba oleh public) hal ini yang mendorong para manajer untuk melakukan tindakantindakan sebagai upaya pemenuhan harapan investor yang salah satunya adalah pengelolaan laba atau earning management.

Kinerja perusahaan sangat kuat dipengaruhi oleh kemampuan manajer dalam membuat keputusan mengenai pasar yang akan dimasuki, produk yang akan diproduksi, beberapa harga produk dan bagaimana aksi yang akan dilakukan terhadap pesaing. Kualitas dari keputusan tergantung tidak hanya pada kemampuan manajer akan tetapi juga pada insentif yang diberikan kepada manajer. Terkadang manajer lebih mementingkan kepentingan sendiri daripada memaksimalkan kesejahteraan pemegang saham sehingga keputusan yang dihasilkan menjadi 
tidak optimal. Manajer mengambil kebijakan investasi, operasi atau keuangan yang sesuai dengan resiko mereka atau pilihan waktu daripada pemegang saham. Pemegang saham sebagai principal memberikan kepada agen untuk menjalankan perusahaan. Agen dalam pengertian ini adalah manajer. Konflik dari kedua pihak akan muncul ketika manajer memiliki kepentingan yang berbeda dari pemegang saham. Para pemegang saham menginginkan agar manajer menghasilkan keputusan yang memaksimalkan kekayaan mereka, akan tetapi terkadang manajer berperilaku sebaliknya dengan mengambil keuntungan pribadinya.

\section{Struktur Kepemilikan}

Sugiato (2009 : 59), Struktur kepemilikan adalah struktur kepemilikan saham, yaitu perbandingan jumlah saham yang dimiliki oleh orang dalam (insiders) dengan jumlah saham yang dimiliki oleh investor. Atau dengan kata lain struktur kepemilikan saham adalah proposi kepemilikan instutisional dan kepemilikan manajemen dalam kepemilikan saham perusahaan. Dalam menjalankan kegiatannya, suatu perusahaan diwakili oleh direksi (agents) yang ditunjuk oleh pemegang saham (principals)

Made Pratiwi (2011 : 41), Struktur kepemilikan terdiri dari kepemilikan saham oleh manajer dan direksi, kepemilikan saham oleh pihak institusi dan kepemilikan saham oleh pihak investor individual.

Struktur kepemilikan saham tercermin baik melalui instrument saham maupun instrument hutang sehingga melalui struktur tersebut dapat ditelaah kemungkinan bentuk masalah keagenan yang akan terjadi. Ada beberapa hal yang perlu diperhatikan dalam struktur kepemilikan saham, antara lain:

1. Kepemilikan sebagian kecil perusahaan oleh manajemen mempengaruhi kecendrungan untuk memaksimalkan nilai pemegang saham dibanding sekedar mencapai tujuan perusahaan semata.

2. Kepemilikan yang terkosentrasi memberi insentif kepada pemegang saham mayoritas untuk berpartisipasi secara aktif dalam perusahaan.

3. Identitas pemilik menentukan prioritas tujuan social perusahaan dan maksimalisasi nilai pemegang saham, misalnya perusahaan milik pemerintah cenderung untuk mengikuti tujuan politik dibanding tujuan perusahaan. 


\section{Saham}

Saham merupakan instrument investasi yang banyak dipilih para investor karena saham mampu memberikan tingkat keuntungan yang menarik (www.idx.co.id).

Fahmi (2012:80) saham (stock) adalah :

a. Tanda bukti penyertaan kepemilikan modal / dana pada suatu perusahaan

b. Kertas yang tercantum dengan jelas nilai nominal, nama perusahaan dan diikuti dengan hak dan kewajiban yang jelaskan kepada setiap pemegangnya.

c. Persediaan yang siap untuk dijual

Menurut Husnan (2002:303) sekuritas (saham) merupakan secarik kertas yang menunjukkan hak pemodal (yaitu pihak yang memiliki kertas tersebut) untuk memperoleh bagian dari prospek atau kekayaan organisasi yang menerbitkan sekuritas tersebut dan berbagai kondisi yang memungkinkan pemodal tersebut menjalankan haknya.

Sedangkan menurut Tandelilin (2001:18) saham merupakan surat bukti bahwa kepemilikan atas aset-aset perusahaan yang menerbitkan saham. Jadi, saham adalah surat berharga yang diperdagangkan di pasar modal yang dikeluarkan oleh sebuah perusahaan yang berbentuk Perseroan Terbatas (PT), dimana saham tersebut menyatakan bahwa pemilik saham tersebut adalah juga pemilik sebagian dari perusahaan tersebut (didukung oleh penelitian dari Indradinata et al, 2019).

Menurut Fahmi (2012: 80), dalam pasar modal ada dua jenis saham yang paling umum dikenalboleh public, yaitu saham biasa (common stock) dan saham preferen (preference stock) kedua saham ini memiliki arti dan aturan masing - masing.

a. Saham Biasa (common stock) adalah surat berharga yang dijual oleh suatu perusahaan yang menjelaskan nilai nominal (rupiah, dolar, yen, dan sebagainya). Pemegang saham biasa diberi hak untuk mengikuti Rapat Umum Pemegang Saham (RUPS) dan Rapat Umum Pemegang Saham Luar Biasa (RUPSLB), serta berhak untuk menentukan apakah apakah akan membeli right issue (penjualan saham tebatas) atau tidak. Pda akhir tahun pemegang saham biasa akan memperoleh keuntungan dalam bentuk deviden.

b. Saham Preferen saham preferen (preference stock) adalah suatu surat berharga yang dijual oleh suatu perusahaan yang menjelaskan nilai nominal (rupiah, dolar, yen, dan sebgaainya) yang member pemegangnya pendapatn tetap dalam bentuk deviden 
yang kan diterima stiap kurtal (tiga bulanan). Jenis - jenis saham preferen ini antara lain saham preferen yang dapat dikonversikan ke saham biasa (convertible preferred stock), saham biasa callable (callable prefered stock) saham preferen dengan tingkat deviden yang mengambang (floating atau adjustable - rate preferred stock).

Nilai dari suatu saham dapat memiliki empat konsep, Martalena dan Maya (2011 : 57) :

1. Nilai nominal

Merupakan nilai perlembar saham yang berkaitan dengan akuntansi dan hokum. Nilai ini diperlihatkn pada neraca perusahaan ddan merupakan modal disetor penuh dibagi jumlah saham yang sudah diedarkan

2. Nilai buku perlembar saham menunjukan nilai aktiva bersih perlembar saham yang merupakan nilai euitas dibagi dengan jumlah lembar saham.

3. Nilai pasar

Nilai suatu saham yang ditentukan oleh permintaan dan penawaran yang terbentuk dibursa saham.

4. Nilai intrinsic

Merupakan harga wajar saham yang mencerminkan harga saham yang mencerminkan harga saham yang sebenarnya. Nilai intrinsic ini merupakan nilai sekarang dari semua arus kas dimasa yang akan datang (yang berasal dari capital gain dan dividen)

\section{Kepemilikan Saham}

Kepemilikan saham merupakan besarnya saham yang dijual dibursa, tipe dari kepemilikan saham ini yaitu pemilika saham yang memiliki sebagian saham dari suatu perusahaan. Dari saham yang dimiliki ini maka akan didapat dividen, deviden yang dibagikan dihitung dari jumlah lembar saham yang dimilki oleh pemilik saham.

Saham dapat didefinisikan sebagai tanda bukti kepemilikan terhadap suatu perusahaan atau perseroan terbatas oleh seseorang atau badan yang diwujudkan pada selembar kertas yang menyatakan bahwa pemilik kertas tersebut merupakan pemilik perusahaan yang menerbitkan surat beharga tersebut yang kepemilikannya sebesar pernyataan yang ditanamkan dalam perusahaan.

Hak utama yang menyertakan kepemilikan saham adalah sebagai berikut :

1. Hak untuk memberikan suara dalam hal-hal yang terkait dengan perusahaan 
2. Hak untuk mendapatkan bagian dari distribusi laba

3. Hak mendapatkan bagian atas aktiva perusahaan saat perusahaan likuidasi.

\section{Manfaat Kepemilikan Saham}

Pada dasarnya, ada dua keuntungan yang diperoleh investor dengan membeli atau memiliki saham (www.idx.co.id).

a. Deviden

Merupakan pembagian keuntungan yang diberikan perusahaan dan berasal dari keuntungan yang dihasilkan oleh perusahaan. Deviden diberikan setelah mendapat persetujuan dari pemegang saham dalam RUPS. Deviden yang dibagikan perusahaan berupa deviden tunai. Artinya kepada setiap pemegang saham diberikan deviden berupa uang tunai dalam jumlah rupiah tertentu untuk setiap saham, atau dapat pula berupa deviden dalam bentuk saham yang dibagikan kepada setiap pemegang saham. Sehingga jumlah saham yang dimiliki akan bertambah dengan adanya pembagian deviden saham.

b. Capital gain

Merupakan selisih antara harga beli dan harga jual. Capital Gain terbentuk dengan adanya aktivitas perdagangan saham di pasar sekunder. Selain perolehan deviden dan Capital Gain, pemegang saham memiliki hak suara dalam RUPS untuk menentukan jalannya perusahaan serta dapat menggunakan sertifikat tersebut sebagai jaminan tambahan dalam memperoleh kredit dari perbankan.

\section{Kepemilikan Saham Manajerial}

Tarigon, Josua dan Yulius Yogi Chritiawan (2007 : 2), Kepemilikan manajerial merupakan kondisi di mana manajer memiliki saham perusahaan atau dengan kata lain manajer tersebut sekaligus sebagai pemegang saham perusahaan. Wahidahwati (2002 : 607), mendefinisikan kepemilikan manajerial sebagai tingkat kepemilikan saham pihak manajemen yang secara aktif ikut dalam pengambilan keputusan, misalnya direktur, manajemen, dan komisaris. Dari berbagai pengertian di atas dapat disimpulkan bahwa kepemilikan manjerial merupakan kondisi di mana manajer perusahaan merangkap jabatan sebagai manajemen perusahaan sekaligus pemegang saham yang turut aktif dalam pengambilan keputusan.

Selaras dengan Tarigan, Josua Yulius Yogi Christiawan (2007 : 2) yang menyatakan bahwa dalam perusahaan dengan kepemilikan manajerial, manajer yang sekaligus pemegang saham tentunya akan menyelaraskan kepentingannya sebagai manajer dengan kepentingannya sebagai pemegang saham. Dengan demikian, manajer akan bertindak secara hati-hati dalam 
mengambil keputusan karena mereka akan turut menanggung hasil keputusan yang diambil.

Dengan kepemilikan dan pengelolaan perusahaan tidak dijalankan secara terpisah, maka masalah teknis tidak akan muncul. Pemilik (pemegang saham) bertujuan untuk memaksimumkan kekayaannya dengan melihat ini sekarang dari arus kas yang dihasilkan oleh investasi perusahaan sedangkan manajer bertujuan pada peningkatan pertumbuhan dan ukuran perusahaan. Tujuan manajer ini dilandasi oleh dua alasan, yaitu:

1. Pertumbuhan yang meningkat akan memberikan peluang bagi manajer bawah dan menengah untuk dipromosikan. Selain itu, manajer dapat membuktikan diri sebagai karyawan yang produktif sehingga dapat diperoleh penghargaan lebih awal dari wewenang untuk menentukan pengeluaran (biaya-biaya).

2. Ukuran perusahaan yang semakin besar memberikan keamanan pekerjaan atau mengurangi kemungkinan lay-off dan kompensasi yang semakin besar. Semakin besar proposi kepemilikan manajemen pada perusahaan, maka manajemen cenderung berusaha lebih giat untuk kepentingan pemegang saham yang tidak lain adalah dirinya sendiri. Kepemilikan saham manajerial akan membantu penyatuan kepentingan antara manajer dengan pemegang saham. Kepemilikan manajerial akan mensejajarkan kepentingan manajemen dengan pemegang saham, sehingga manajer ikut merasakan secara langsung manfaat dari keputusan yang diambil dan ikut pula mananggung kerugian sebagai konsekuensi dari pengambilan keputusan yang salah. Argument tersebut mengindikasikan mengenai pentingnya kepemilikan manajerial dalam struktur kepemilikan perusahaan.

\section{METODE PENELITIAN}

Penulis melakukan penelitian atau pengambilan data yaitu di Pusat Informasi Pasar Modal - Padang yang beralamat di Jl. Pondok No. 90A Padang-Indonesia. Phone : (0751) 811330, Fax : (0751) 811340, sebagai perwakilan dari Bursa Efek Indonesia (BEI) untuk cabang daerah Padang.Penelitian ini dilakukan pada perusahaan pertambangan yang terdaftar di BEI.

Hipotesis dalam penelitian ini menggunakan model regresi linier berganda. Adapun model regresinya adalah sebagai berikut:

$\mathrm{Y}=\mathrm{a}+\mathrm{b} 1 \mathrm{X} 1+\mathrm{b} 2 \mathrm{X} 2+\mathrm{b} 3 \mathrm{X} 3+\mathrm{b} 4 \mathrm{X} 4+\mathrm{e}$ 


\section{HASIL DAN PEMBAHASAN}

Hasil uji hipotesis pengaruh struktur kepemilikan saham terhadap kinera perusahaan dapat dilihat dari analisis dari analisis regresi linear berganda yang tercangkup pada tabel dibawah ini:

\section{Analisi regresi linear berganda}

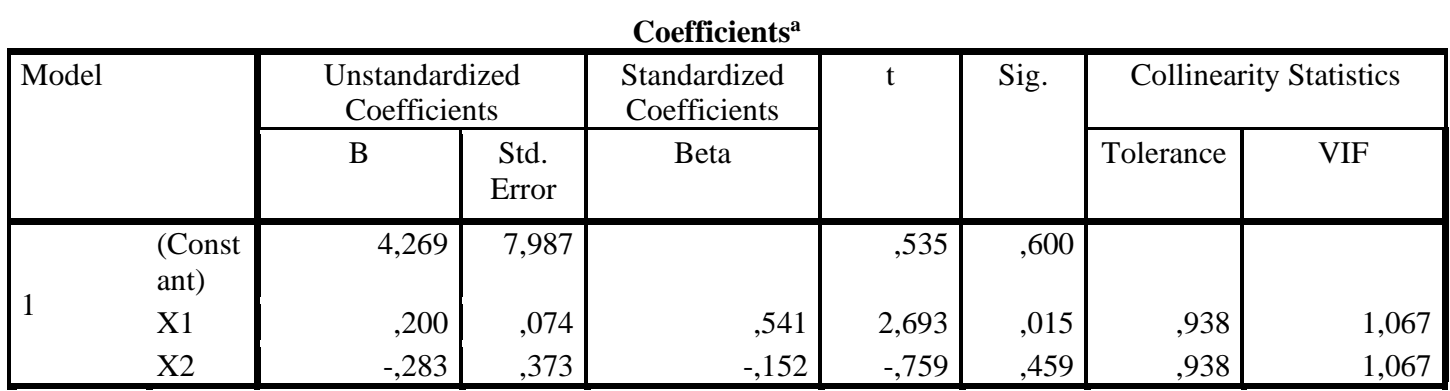

a. Dependent Variable:

Sumber : data sekunder yang diolah

Berdasarkan analisis regresi seperti tertera pada ringkasan tabel diatas diperoleh persamaan model regresi yaitu:

$\mathrm{ROA}=4,269+0,200 \mathrm{X} 1-0,283 \times 2+\mathrm{e}$

Dari persamaan regresi tersebut dapat diungkapan:

\section{Konstanta}

Nilai konstanta yang diperoleh sebesar 4,269. Hal ini berarti bahwa jika variabel tingkat kepemilikan publik dan kepemilikan asingnya adalah nol maka ROA nilainya 4,269

\section{Koefiesien regresi (X1)}

Nilai koefisien regresi variabel kepemilikan publik sebesar 0,200 mempunyai arti bahwa jika kepemilikan asing (0) maka setiap peningkatan satu satuan tingkat kepemilikan publik akan mengakibatkan kenaikan ROA sebesar 0,200.

\section{Hasil perhitungan regresi (a) model summary}

\begin{tabular}{|l|r|r|r|r|r|}
\hline Model & R & R Square & Adjusted R Square & $\begin{array}{c}\text { Std. Error of the } \\
\text { Estimate }\end{array}$ & Durbin-Watson \\
\hline 1 &, $597^{\mathrm{a}}$ &, 357 &, 281 & 7,27580 & 1,062 \\
\hline
\end{tabular}

a. Predictors: (Constant), X2, X1

b. Dependent Variable: Y

Sumber : Data sekunder yang diolah

Berdasarkan tabel 4.4 diatas dapat dilihat bahwa nilai koefisien determinasi $\left(R^{2}\right)$ sebesar 0,357 atau 35,7\%. Dimana kontribusi variabel bebas kepemilikan publik dan 
kepemiikan asing terhadap ROA sebesar 35,7\% dan sisanya 64,7\% dipengaruhi oleh variabel lain yang tidak diteliti dalam penelitian

\section{Pengujian dengan koefisien regresi parsial (uji t)}

Pengaruh struktur kepemilikan saham secara parsial di uji dengan uji t yang bertujuan untuk menguji signifikasi pengaruh satu variabel bebas secara individu terhadap variabel terikat. Hasil pengujian SPSS untuk memprediksi kinerja perusahaan dengan menggunakan variabel kepemilikan publik dan kepemilikan asing dapat dilihat pada tabel 4.8 sebagai berikut:

a. Kemampuan kepemilikan publik mempengaruhi kinerja perusahaan pertambangan Berdasarkan tabel 4.8 dapat diketahui bahwa kepemilikan publik menghasilkan nilai t sebesar 2,693 variabel ini mempunyai nilai signifikan sebesar 0,015 yang apabila dibandingkan dengan derajat kesalahan yang telah ditentukan sebesar 5\% variabel ini, termasuk signifikan. Nilai signifikan variabel kepemilikan publik lebih kecil dari derajat kesalahan $(0,015<0,05)$ yang artinya bahwa Ho ditolak dan Ha diterima. Dari hasil uji t disimpulkan bahwa kepemilikan publik berpengaruh signifikan terhadap kinerja perusahaan.

\section{Pengujian Terhadap Koefisien Regresi Secara Simultan (uji f)}

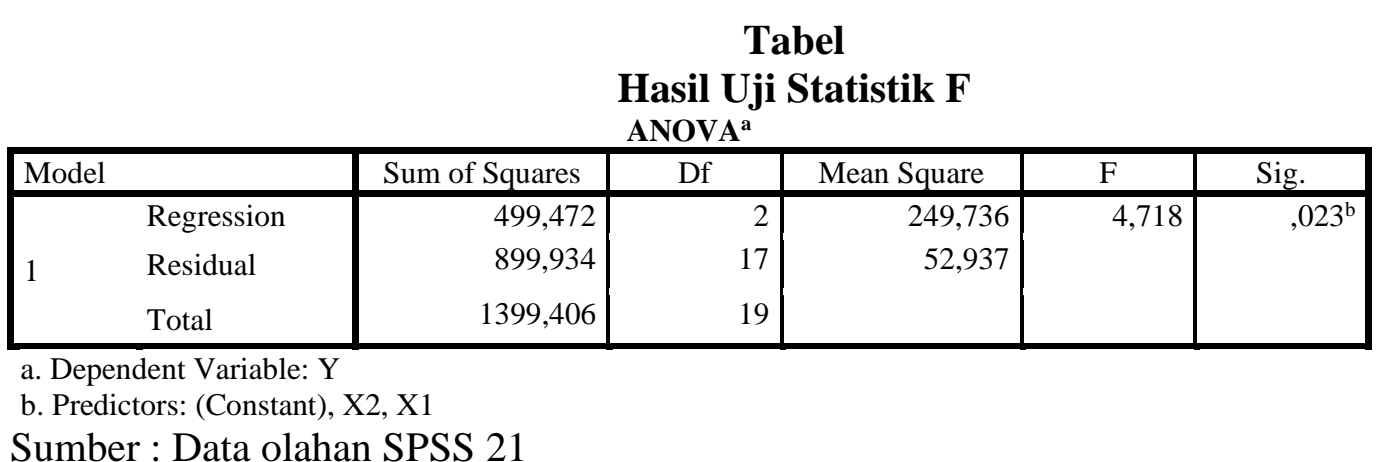

Uji ini dilakukan untuk menguji signifikan simultan yaitu uji $\mathrm{F}$, untuk menunjukkan apakah variabel bebas secara simultan atau bersama-sama mempunyai pengaruh terhadap variabel independen ditolak. Dari tabel 4.7 dapat diketahui signifikan uji tersebut 0,023 yang berarti lebih kecil dari derajat kesalahan yaitu $5 \%(0,023<0,05)$. Dari uji F ini berarti H0 ditolak dan H3 diterima. Dengan demikian tingkat kepemilikan publik dan kepemilikan asing secara bersama-sama berpengaruh signifikan terhadap kinerja perusahaan 
Berdasarkan output regresi linear berganda diatas, model analisis regresi berganda yang digunakan dalam penelitian ini adalah dapat dirumuskan sebagai berikut:

$\mathrm{ROA}=4,269+0,200 \mathrm{X} 1-0,283 \mathrm{X} 2+\mathrm{e}$

Konstanta menunjukkan angka sebesar 4,269 yang berarti tanpa variabel independen kinerja perusahaan tidak memiliki nilai sendiri. Hal ini menandakan tidak adanya pengaruh variabel kepemilikan publik dan kepemilikan asing. Kepemilikan publik mununjukkan angka 0,200 yang mempunyai arti bahwa jika kepemilikan asing (0) maka setiap peningkatan kepemilikan publik sebesar satu-satuan akan meningkatkan kinerja perusahaan sebesar 0,200. Kepemilikan asing menunjukkan angka sebesar -0,283 mempunyai arti bahwa jika kepemilikan publik (0) maka setiap penurunan sebesar satu-satuan akan menurunkan kinerja perusahaan sebesar 0,283 .

Nilai R square sebesar 0,357 dimana hal ini berarti 35,7\% nilai kinerja perusahaan pertambangan dapat dijelaskan oleh kedua variabel bebas kepemilikan publik dan kepemilikan asing, sedangkan sisanya 64,3\% dipengaruhi oleh variabel lain yang tidak diteliti dalam penelitian ini.

\section{PENUTUP}

Variabel kepemilikan publik secara parsial berpengaruh signifikan terhadap kinerja perusahaan pada perusahaan pertambangan yang terdaftar di Bursa Efek Indonesia (BEI) hasil uji t. Variabel kepemilikan asing secara parsial tidak berpengaruh signifikan terhadap kinerja perusahaan pada perusahaan pertambangan yang terdaftar di Bursa Efek Indonesia (BEI) hasil uji t. Secara simultan kepemilikan publik dan kepemilikan asing berpengaruh signifikan secara bersama-sama terhadap kinerja perusahaan pada perusahaan pertambangan yang terdaftar di Bursa Efek Indonesia (BEI) dapat dilihat pada hasil uji f.

Adapun saran yang dapat diberikan oleh penulis, antara lain : 1) Bagi perusahaan, perusahaan harus lebih memperhatikan faktor kinerja perusahaan yang diukur oleh struktur kepemilikan saham. Perusahaan harus menyediakan informasi yang akurat, actual dan bertanggung jawab guna memudahkan bagi investor dalam mengambil keputrusan untuk menanamkan investasi pada perusahaan. 2) Bagi penelitian selanjutnya, penelitian lebih lanjut dapat menggunakan metode lain yang dimungkinkan lebih baik dari analisis varibel yang digunakan dalam penelitian ini. Dengan penelitian lain diharapkan dapat diperoleh hasil penelitian yang lebih beragam dengan menambahkan beberapa variabel lain seperti kepemilikan manajemen atau kepemilikan institusional dan lain-lain. Selain itu untuk 
penelitian selanjutnya diharapkan mengambil periode yang lama sehungga hasil penelitian lebih akurat dan mencerminkan keadaan yang sebenarnya terkait pengaruh faktor-faktor terhadap kinerja perusahaan. 


\section{DAFTAR PUSTAKA}

Fahmi, I. (2011). Analisis Laporan Keuangan. Lampulo: Alfabeta.

Fahmi, I. (2012). Analisis Laporan Keuangan. Cetakan Ke-2. Bandung: Alfabeta.

Ghozali, I. (2011). Aplikasi Analisis Multivariate Dengan Program IBM SPSS 19 (edisi kelima). Semarang: Universitas Diponegoro.

Husnan, S. (2002). Dasar-dasar Teori Portofolio dan Analisis Sekuritas. Edisi ketiga.Yogyakarta: AMP YKPN.

Indradinata, A., Suardana, I.B.R., Darma, G.S. (2019). Faktor Penentu Naik-Turunnya Harga Saham di Bursa Efek Indonesia, Jurnal Manajemen \& Bisnis, 16 (2): 14-35.

Ismiyanti dan Hanafi. (2013). Persamaan Simultan antara Kepemilikan Manajerial, Kepemilikan Institusional, Risiko, Kebijakan Hutang dan Kebijakan Dividen. Simposium Akuntansi, Fakultas Ekonomi.

Kurniawan, H., dan Indrianto, N. (2000). Analisis Hubungan Antara Arus Kas Dari Aktiva Operasi dan Data Akrual Dengan Return Saham: Studi Empiris Pada Bursa Efek Jakarta, Jurnal Bisnis dan Akuntansi, 2 (3): 207-224.

Lestari, M.I., dan Sugiharto, T. (2007). Kinerja Bank Devisa Dan Bank Non Devisa Dan Faktor-Faktor Yang Mempengaruhinya. Proceeding PESAT (Psikologi, Ekonomi, Sastra, Arsitek \& Sipil). Fakultas Ekonomi, Universitas Gunadarma.

Mardiyanto, H. (2009). Intisari Manajemen Keuangan. Jakarta: Grasindo.

Martalena dan Malinda, M. (2011). Pengantar Pasar Modal. Yogyakarta: Andi Offset.

Nuraeni, D. (2010). Pengaruh struktur Kepemilikan Saham Terhadap Kinerja Perusahaan.

Permanasari, W.I. (2010). Pengaruh Kepemilikan Manajemen, Kepemilikan Institusional dan Corporate Social Responsibility terhadap Nilai Perusahaan. Skripsi, Universitas Diponegoro, Semarang.

Ross, Westerfield, Jordan. (2008). Pengantar Keuangan Perusahaan (Corporate Finance Fundamental), Edisi Kedelapan. 4 (2): 126-140.

Setiawan, M. (2006). Pengaruh Struktur Kepemilikan, Karakteristik Perusahaan, dan Tata Kelola Korporasi terhadap Kinerja Perusahaan.

Sedarmayanti. (2011). Manajemen Sumber Daya Manusia, Reformasi Birokrasi dan Manajemen Pegawai Negri Sipil (cetakan kelima). Bandung: PT Refika Aditama.

Sugiarto. (2009). Struktur Modal, Struktur Kepemilikan Perusahaan, Permasalahan Keagenan dan Informasi Asimetri. Edisi Pertama. Yogyakarta: Graha Ilmu.

Tandelilin, E. (2001). Analisis Investasi dan Manajemen Portofolio. Edisi Pertama. 
Yogyakarta: BPFE.

Tarigon, Josua dan Yulius Yogi Chritiawan. (2007). Kepemilikan Manajerial: Kebijakan Hutang Kinerja dan Nilai Perusahaan, Jurnal Akuntansi dan Keuangan, 9 (1): 1-8.

Uchida, K. (2006). Pengaruh Kinerja Perusahaan dan Kepemilikan Manajerial terhadap Leverage.

Wahidahwati. (2002). Pengaruh Kepemilikan Manajerial dan Kepemilikan Institusional pada Kebijakan Hutang Perusahaan: Sebuah Perspektif Theory Agency, Jurnal Riset Akuntansi Indonesia, 5 (1): 1-16.

Welim, M.F. Rusiti, Ch. (2014). Pengaruh Kepemilikan Manajerial dan Kepemilikan Institusional terhadap Nilai Perusahaan.

Weston, J. Fred., dan Thomas E. Copeland. (1995). Manajemen Keuangan, Edisi 8. Jilid 1. Alihbahasa: Jaka Wasana dan Kirbrandoko. Jakarta: Gelora Aksara Pratama.

Widarjo, W. (2010). Pengaruh Ownership Retention, Investasi Dari Proceeds, Dan Reputasi Auditor Terhadap Nilai Perusahaan Dengan Kepemilikan Manajerial Dan Institusional Sebagai Variabel Pemoderasi. Simposium Nasional Akuntansi XIII.

Wiranata, Y.A. (2013). Pengaruh Struktur Kepemilikan terhadap Kinerja. 